\title{
Practical Problems of Legal Regulation of Customs Duties Developing an International Trade Between the Republic of Lithuania And East Asian Countries
}

\begin{abstract}
For more than ten years (since 2004) the Republic of Lithuania is a member of the EU and is realizing its economic and trade relations with other foreign countries, and regulating customs duties according to the requirements of the EU Common Commercial Policy. However, in the recent years foreign trade (in particular - exports of goods) remained one of the main factors which increased an economic growth (recovery) in the Republic of Lithuania after the global economic crisis of the world, which began in 2008. In this context, the search for new markets and expansion of trade relations with new trade partners in Asia became essential in order to diversify the structure of the national economy and avoid dependence on traditional trade partners, such as Russia. Taking into account this strategic goal, the article seeks to answer a question whether an existing foreign trade regulation system ensures the status of Lithuania as an attractive partner of foreign trade with East Asian countries (Taiwan, Hong Kong, South Korea and Singapore) and what regulatory instruments (customs duty rules and procedures) should be used on the national level to ensure cooperation with these countries. In order to answer this problematic question, the first chapter of the article overviews general tendencies in Lithuanian foreign trade with the countries of East Asia, while the second chapter is dedicated to describe regulatory regime for import customs duties on the national level (in line with the major provisions of the EU Common Commercial Policy). The practical problems and obstacles to international trade are presented in the third chapter and are illustrated by the examples of case law, which was formed in disputes relating to the decisions and actions of Lithuanian national customs authorities for the period from 1 May, 2004 (since entry to the EU)).
\end{abstract}

Santrauka: Jau daugiau nei dešimt metų (nuo 2004), Lietuvos Respublika yra ES nare ir realizuoja savo ekonominius ir prekybinius santykius su kitomis užsienio valstybèmis bei reguliuoja tarptautinės prekybos apmokestinimą muitais laikydamasi ES bendrosios prekybos politikos reikalavimų. Pastaraisiais metais būtent užsienio prekyba (ypač prekių eksportas) išliko vienu iš svarbiausių veiksnių, kuris skatino Lietuvos Respublikos ekonominį augimą (ekonomikos atsigavimą) po pasaulinės ekonominès krizès, prasidèjusios 2008 metais Šiame kontekste itin svarbiu tikslu išlieka naujų rinkų paieška ir prekybinių ryšių su naujais prekybos partneriais Azijoje plètojimas, kas yra labai svarbu siekiant diversifikuoti šalies ekonomikos struktūrą ir išvengti priklausomybès nuo tradicinių prekybos partnerių, pavyzdžiui, Rusijos. Atsižvelgiant ị ši strateginį tikslą, straipsnyje siekiama atsakyti ị probleminį klausimą, ar esama užsienio prekybos reguliavimo sistema užtikrina Lietuvos, kaip patrauklios užsienio 
prekybos su Rytų Azijos šalimis (Taivanu, Honkongu, Pietų Korèja ir Singapūru) partnerès statusą, ir kokios reguliavimo priemonès (apmokestinimo muitais taisyklès bei procedūros), turètų būti naudojamos nacionaliniu lygmeniu, siekiant užtikrinti efektyvesnį bendradarbiavimą su šiomis šalimis. Siekiant atsakyti ị ši probleminị klausimą, pirmajame straipsnio skyriuje apžvelgiamos bendrosios Lietuvos užsienio prekybos su Rytų Azijos šalimis tendencijos, 0 antrasis skyrius yra skirtas apibūdinti esamą nacionalinị importo muitų taikymo režimą, kuris privalo būti įgyvendinamas laikantis pagrindinių ES bendrosios prekybos politikos nuostatų. Praktinès problemos ir teisinės kliūtys tarptautinės prekybos su Rytų Azijos šalimis plètrai yra analizuojamos straipsnio trečiajame skyriuje aptariant nacionalinių teismų ir kitų igaliotų institucijų praktiką sprendžiant ginčus, susijusius su Lietuvos nacionalinių muitinės institucijų sprendimais ir veiksmais (laikotarpiu nuo 2004 m. gegužès 1 d., t.y. nuo Lietuvos Respublikos įstojimo ị ES momento)

Keywords: international trade, customs duties, East Asian countries, international trade agreements, EU Common Commercial Policy.

\section{Introduction}

The fundamental objective of global development in the modern era, which is targeted by both the international community and individual countries, is to form favourable conditions for the development of the society and its welfare and to create an environment, which would guarantee equal social and economic conditions for sustainable growth. On the other hand, the processes of globalization, as an exclusive feature of modern social and economic system (Hirst, Thompson 1992; Jusčius 2006), characterize social relations in the modern world. This process means the creation of a single global economy, when the globally geo-dispersed activities are linked into a coherent complex where the interdependence relations link the entities, participating in it (Linarelli, 2014). Thus, sustainable development, economic growth and development objectives of each country are related to globalization. One of the most important and dynamic global economic factors, which is influencing the globalization, is international trade. Accordingly, it is noticed both at theoretical and practical level, that in the current circumstances, no country can achieve economic growth without being present actively in international trade (Laurinavičius et al. 2014).

On the other hand, authors, who are exploring evolution of international economic law and its functioning (Folsom, Gordon, Spanogle 2004; Herdegen 2013; Laurinavičius et al. 2014), emphasizes that although a modern international economic order is regulated by international agreements, conventions and international organizations that help to balance the interests of the countries concerned, at the national level, international trade operators are faced with different legal application of these regulations on the level of domestic (national) law. It should be noted that individual states might restrict international trade in their internal economic law, using tariff and non- 
tariff trade regulation measures. Often it is done even without following the generally recognized principles of free international trade and fair competition. There are various examples of such practices, such as, for example, the trade conflict between the European Union (hereinafter - EU) and Russian Federation which began in the summer of 2014, when the Russian Federation unilaterally adapted restrictions for the importing of certain products in its domestic market ${ }^{1}$.

\section{General tendencies in Lithuanian foreign trade with the countries of East Asia}

The examination of the international trade development tendencies in the EU and the Republic of Lithuania in the context of global economy, we can state that in addition to traditional EU trading partners such as the US, Japan, Norway, Switzerland, Turkey, the recent period was marked by the growing importance of the international trade with so-called "New Leading Powers" - Russia, China and India (Leal-Arcas 2011; Bernatonytè 2011). In this respect it should be noted that China has for many years remained one of the EU's largest trading partners, while trade with Russia and India in the past decade (until 2014) had a tendency to grow, since Russia for a long time remained a major importer of energy resources to the EU. On the other hand, in the middle of 2014 the trade conflict between the EU and Russia began, which prompted the EU to seek new export markets and strengthen trade cooperation with other countries of the world. Analogous issues of international trade cooperation are very important to the Republic of Lithuania, as an EU member state, since after the accession to the EU, more than 20 percent of its foreign trade constituted the trade with the Russian Federation, which, in spite of some fluctuations, has long had a general tendency to grow (increase) (Bernatonytė 2011; Slavickienè, Jatkūnaitė 2006). For example, over the last five years (2010 - 2014) one of key foreign trade partners of the Republic of Lithuania (in the non-EU countries group) were separate BRICS countries - Russia and China. Imports from Russia amounted to more than 5 billion EUR in 2010 and 2014, as well as more than 7 billion EUR in 2011 and 2013. Accordingly, imports from China also rose steadily from 430 million to 666 million EUR over the period 2010-2014. This tendency was also associated with the permanent growth of exports to China. Other major Lithuanian foreign trade partners were the United States and Norway, the imports from which in recent years (2014) was 319 (from US) and 120 (from Norway) million EUR, while the export volume amounted to 904 million EUR (to the US) EUR and 558 million EUR (to Norway) (Lietuvos Respublikos statistikos departamentas 2015). In this context, it is clear that, having such foreign trade structure, which is traditionally dominated by relations with the Russian Federation, the major challenge remains the search for new markets 
and trade relationships with new trading partners in development in order to diversify foreign trade structure and to avoid economic dependence on traditional trade partners (such as Russia).

The analysis of the Lithuanian foreign trade relations with East Asian countries leads to the conclusion, that although volume of foreign trade with these countries was below the volume of trade with main trading partners, but all the time in the last decade ((yrs. $2004-2014)$ have steadily increased - imports from 97.5 (2004) to 130.7 (2014) million EUR and exports from 31.90 (2004) to 86,9 million EUR (2014). This was particularly noticeable during the period before the Global Economic Crisis began in 2008. During 2008 the volume of imports reached 132.6, and export - 87.6 million EUR, although at the start of the economic crisis in 2009 trade volumes dropped by more than 50 percent (imports amounted to 63.4 million EUR, while exports - to 39,10 million EUR) (Lietuvos Respublikos statistikos departamentas 2015). However, as already stated, it was only a temporary disorder and later (in 2014), trade volumes have reached pre-crisis levels. This means that trade relations with East Asian countries is characterized by a coherent trade development and these countries are increasingly becoming a significant foreign trade partners to the Republic of Lithuania. Taking into account this group of countries, the most important partners in import operations, which recorded the highest trading volumes, were Taiwan and South Korea (this state is also one of the main partners of the EU in import operations; Bernatonyte 2011, p. 256), while the main partners for Lithuanian exports were Singapore, Hong Kong and South Korea.

The authors (e.g. Leal-Arcas 2011), who analyses development opportunities of the international trade between the EU and the rest of the world, note that it is particularly important to evaluate what kind of problems arise from the legal regulation of international trade with foreign partners: what is the status of curent legal regulation of these relations and what are the prospects for its development both from the perspective of individual states (trading blocs) and from international level (international economic law). In this respect, certain issues could be distinguished as an objects of a separate legal research such as, for example, whether an international trade regulatory system provided by the EU (and its member states) ensures them the status of an attractive foreign trade partner and which regulatory instruments should be used by the EU (and its member states, including Lithuania) in order to promote the cooperation with these countries, as well as what measures should ensure coordination of international trade policies within the EU (Leal-Arcas 2011, p. 16). In this context, it is necessary to point out that the classic and the most common form of international trade regulation is customs duties (indirect import taxes, levied on imports of goods at the moment of their movement across the state border). As it is emphasized by individual authors (e.g. Thuronyi, 2003; Bossche, 2013), they have a unique role and influence on international trade. 
It should be noted that although the East Asian countries are members of the World Trade Organization (hereinafter - WTO) and an active partners of international trade with the Republic of Lithuania, importance of customs duties for the regulation of an international trade processes in the Republic of Lithuania is not examined in the legal and economic literature. At the national level, only the general issues related to the customs duties regulation prospects after accession to the EU are analysed (Radžiukynas 2011; Raišutis 2005; Povilauskienè 2006; Slavickienė, Jatkūnaitè 2006). Other studies also analyses the general problems of applications of WTO agreements, taking into account specifics of the national legal system (Rimkus, 2006; Daukšienè I., 2011), and problems of legal regulation of international trade in services (Langviniene, Žitkienė, 2011). Only foreign authors (e.g. Leal-Arcas 2011) provide a general insight for the regulation of an international trade with the EU, taking into account the aspect of the tariff regulatory measures (customs duties). In this context, having in mind the objective for the diversification of Lithuanian foreign trade, an important subject of research is the integration of businesses in the EU and the Republic of Lithuania into global market and creation of legal conditions for the development of international trade with the countries of East Asia. These goals, such as integration into emerging markets (including East Asia) and creation of an environment for the international trade, which is conducive to economic growth and their importance are explicitly stressed in the Lithuanian Export Development Guidelines for yrs. 2014-2020, which were approved by the Minister of Economy of the Republic of Lithuania by order No. 4-58, on 27 January, 2014 (Para. 21.3) (Lietuvos Respublikos ūkio ministerija, 2014). In this context, this article, taking into account examples of the national judicial practice, aims to identify the regulatory mechanisms of the legal system of the Republic of Lithuania, constituting tariff (customs duties) barriers to an international trade with East Asian countries and to make proposals for the improvement of national legal regulations in order to create favourable conditions for the development of international trade.

\section{Peculiarities of regulatory regime for import customs duties on the national level after the entry of Lithuania to the European Union}

The EU, as the economic and political bloc of member countries, which are united in a single European internal market in which the free movement of goods and services is ensured, formed in parallel with the regionalization processes in the world and the formation of free trade and single market policies on a regional scale. EU is characterized by its Common Commercial Policy (hereinafter - CCP), which means that foreign trade with third countries (non-EU member states) is regulated on the EU level using common legal provisions and rules (Leal-Arcas 2008). Since 1 May, 2004, The Republic 
of Lithuania joined the EU and took over all the EU international legal obligations towards third countries and international organizations. In this way, the Republic of Lithuania also joined the CCP area where, from a legal point of view, foreign trade is governed based on unanimity.

In practical terms, this means that the processes of legal regulation of international trade are closely related to the regulation of international trade on state level, i.e. to the consolidation, enhancement and development of national law. For this reason, the authors, which examines with the problems of legal regulation of international trade (e.g. Leal-Arcas 2011; Radžiukynas et al. 2011), identifies regulatory concepts of unilateralism, bilateralism/ regionalism, multilateralism/plurilateralism. From an EU perspective, based on concept of unilateralism, the EU, in its sole discretion (unilaterally), imposes the liberalization measures for international trade, which are covered by the Generalized System of Preferences (hereinafter - GSP). Based on the provisions of GSP, the EU does not apply customs duties on goods, imported form individual developing countries. The multilateral dimension of the CCP includes the implementation of multilateral agreements WTO agreements with the third countries. The bilateral (regional) dimension of the CCP means that the EU, using the instruments of the CCP, develop economic and trade relations with the third countries through bilateral preferential agreements creating free-trade zones. Since 2009, The Treaty of Lisbon has increased the EU Parliament's role in this field, simplifying the EU's foreign trade policy, abandoning concept of mixed international agreements, which belonged to the competence of both the Community (EU) and its Member States and not providing requirements to ratify these agreements in national parliaments (Woolcook, 2008, Radžiukynas et al. 2011). Currently, all trade agreements in the EU belong to its competence and must ratified by the EU Parliament and the Council.

The examination of the international trade regulation regimes, which the EU applies to the East Asian countries, leads to the conclusion that in practice various not identical regulatory levels are applied. In particular, it is emphasized that none of the East Asian countries - South Korea, Taiwan, Singapore and Hong Kong, as a special administrative region of the People's Republic of China, - are entitled to the measures of the EU GSP scheme. The EU applies the bilateral (regional) CCP concept towards South Korea, which means that EU-South Korea Free Trade Agreement 2011 (FTA) has entered into force in July 2011 and goes further than any previous agreements in lifting trade barriers and it is the EU's first trade deal with an Asian country. The agreement eliminates duties for industrial and agricultural goods in a progressive, systematic approach: the majority of import duties were removed already when the free trade agreement entered into force on 1 July 2011 and on 1 July 2016, import duties will be eliminated on all products except for a limited number of agricultural products. The same policy trend is applied 
to the Singapore, since the EU and Singapore completed the negotiations for a comprehensive free trade agreement on 17 October 2014 and the initialled agreement needs to be formally approved by the European Commission and ratified by the European Parliament (European Commission 2015). Therefore, the current EU-Singapore international trade relations are governed by the WTO agreements (concept of multilateralism) in accordance with the general principles of most favoured nation, non-discrimination and etc. International trade between the Taiwan and Hong Kong (as a special administrative region of China) and its tariff regulatory measures (customs duties) are regulated in the same way and using the same concept. Following the 'one-China' policy, the EU does not have diplomatic or formal political relations with Taiwan. However, the EU and Taiwan have a structured dialogue where in the annual consultations, all trade policy issues are addressed, including WTO obligations and issues of bilateral concern. The EU's policy towards the Hong Kong Special Administrative Region (SAR) is also based on the objectives for moving towards cooperation in key areas, including trade and customs, but maintaining the importance of the 'one country, two systems' principle, issued in the context of the handover of Hong Kong to Chinese sovereignty since 1997 (The Directorate General for Trade of the European Commission 2015).

It should be noted that, for example, nor the use of Common Customs Tariff for the taxation of international trade with the third countries (as an essential part of the EU CCP), nor the identical customs origin and customs valuation rules for the goods imported to the EU (established by the Community Customs Code 1992) does not eliminate a significant impact of the separate EU member states on the regulation of international trade. Freedom of international trade and the customs system, which is ensuring its functioning in the global market, the ability to purchase goods in any country of the world and to sell them in another, as well as the opportunity to export the goods produced in the country freely is useful for all states. In this respect, within the EU individual EU Member States may have a substantial impact on international trade, implementing and applying their national customs rules, creating the precedents for their application (on the national level) or regulating administrative procedures in the national customs authorities. These factors can directly determine the size of customs fees and duties collected by the individual state and influence its economic situation (Baronaite 2010). For example, the rigid national rules or practices of operation of national customs institutions may persuade a person wishing to import goods for sale Lithuania not to formalize their free release into the circulation (with it the obligation to pay customs duty is usually related) in the Lithuanian customs authorities. An importer may do so in any other European Union member state, and after paying import taxes there, to bring goods into Lithuania, accordingly the Republic of Lithuania does not receive its income to the state 
budget in the form of customs duties. Autonomy of the EU Member States in regulating economic trade relations, which are important for the ensuring of functioning of the global market, is also reflected in other aspects. For example, although partially harmonized, their customs law may be assessed as a product of sovereign legislative initiatives, clearly defining the areas the priority of national legislations is ensured, such as organization of the activities of customs institutions, their functions, authorities, competence of customs officials, the systems for management of their activities and career opportunities (Raišutis 2005; Laurinavičius et al. 2014).

In this respect, we can fully agree with the individual authors (e.g. Leach 2007), who believes that the restrictions of national jurisdiction (sovereignty) of EU member states on inter alia the formation of economic policies relevant to their functioning of the global market, are applied in certain specific areas. Accordingly, the transfer of the national government's functions to the EU is partial. So, even the implementation of CCP for the regulation of the EU's international trade, albeit limiting the sovereignty of EU Member States on these issues, actually does not eliminate it, providing opportunities for national measures to have a direct effect on the foreign (international) trade. The Republic of Lithuania is the member of the EU for more than 10 years, and, therefore, must realize its economic and trade relations with other foreign countries, regulate its taxation with import duties, according to the provisions of the EU's CCP (common foreign trade policy). However, at the national level Lithuania is interested in promoting international trade with an important foreign trade partners, providing, inter alia, the creation of effective national regulations and procedures that guarantee a favourable business environment, stimulate businesses to choose Lithuania as their import operations partner, thus contributing to the implementation of the fiscal goals of the state, related to the collection of import taxes (customs duties, import value added tax and excise duties).

\section{The practical problems of international trade regulation with the countries of East Asia: examples of Lithuanian case law}

\section{General remarks}

International trade is inextricably linked with the responsibilities of certain countries (or their groups) to ensure the protection of their internal market, which primarily are related to the establishment and application of customs duties on imported goods of foreign origin. Specific duty rate is usually determined by three main elements, the price, that is the customs value of imported goods; customs origin, that is state or region in which goods originated (were produced) and classification (code) ${ }^{2}$, i.e. the heading 
or subheading of the Combined Nomenclature used to identify the goods for customs purposes (Baronaite 2010). The effectiveness of this internationally recognized system used for the assessment of customs duties and the emerging practical problems in the Republic of Lithuania can be illustrated by the practice of tax disputes, concerning the calculation of import taxes and other decisions or activities of customs authorities which were challenged in the national competent institutions (courts and other independent dispute resolution bodies). It should be noted that, in accordance with the Law on Tax Administration of Lithuanian Republic (c. IX) and its provisions, which are in force since the 1 May 2004 (Lietuvos Respublikos Seimas 2004), tax disputes in the Republic of Lithuania, are investigated using the mandatory pre-trial procedure. In addition to the tax authorities themselves, a special independent non-judiciary institution - Commission on Tax Disputes under the Government of the Republic of Lithuania - and the courts (Vilnius Regional Administrative Court and the Supreme Administrative Court of Lithuania) must examine such disputes.

The analysis of the relevant case law leads to the conclusion that the growth of international trade with the countries of East Asia and rising import volumes from these countries was related to the increase of litigation cases, concerning taxation of imported goods in Lithuania. For example, before 2013 Lithuanian tax dispute authorities (courts and the Commission on Tax Disputes) had to examine not more than three complaints of the importers from East Asia countries. However, in 2014, this number has increased to six complaints (cases). During the whole reporting period (yrs. 2004 - 2014), the competent authorities in the Republic of Lithuania have examined 14 of such cases can be specified as follows: 5 cases related to the taxation of goods imported from Taiwan, 4 cases - related to imports both from Singapore and South Korea and 1 case related to imports from Hong Kong. This is obviously, is related to the fact that, as it was mentioned above, the main foreign trade partners of the Republic of Lithuania in East Asia region are South Korea and Taiwan.

It is also obvious that the number of these cases was significantly smaller than the number of disputes, related to the taxation of goods imported from the largest foreign trade partners of Lithuanian Republic, such as Russia, China or the United States (in this case, just in the last five years (yrs. 20102014) competent national authorities examined more than 100 such disputes). A comparison of these disputes and the legal problems raised in them, allows to observe some general trends and to draw the conclusions about certain systemic problems of national legal basis, its application in practice and the possible disadvantages, which hinder an international trade. First of all, this is related to the correct determination of the customs value (the proper application of customs valuation methods which are described in international legislation), distribution of the burden of proof on the customs origin of goods 
between the taxpayer (importer) and the tax authorities (customs offices) and the functioning of national system used for the tariff classification of goods for customs purposes. The same practical problems are observed by the scientific legal literature, which states that most disputes with customs authorities are usually caused by improper determination of value of goods for customs purposes, as well as issues of improper determination of customs origin (Baronaitė 2010; Medelienè, Paulauskas 2008; Radžiukynas 2011). Some authors (Laurinavičius et al. 2014, p. 201) has recently also observed the growing number of disputes with customs authorities on the stage of approval of tariff classification of imported goods. Analogous trends are mostly reflected in the specific tax disputes, which arise between the national customs authorities and taxpayers (importers) on taxation of goods imported from the countries of East Asia. Therefore, it can be stated that although the Republic of Lithuania is the member of WTO and the EU for more than 10 years, the factors, which are causing such problems, are not properly identified and solved in a manner, which is consistent with the international standards (this also includes the legislative level).

\section{Problems of customs valuation of imported goods}

In this regard, in particular it is important to mention the issues on customs valuation of goods. The practice of national tax dispute authorities since joining the EU up to the current moment (2014), shows that such questions have been addressed, above all, in cases on taxation of goods, imported from South Korea, on determining of their proper customs value. Specifically, in these disputes (cases of the Commission on Tax Disputes A. G. v Customs Department under the Ministry of Finance of Lithuanian Republic (2006) and E. D. v Customs Department under the Ministry of Finance of Lithuanian Republic (2006)) were the importers (taxpayers) raised the issue for the legality of additional taxation of imported leather jackets (importing country - South Korea), when national customs authorities refused to apply the transaction value method as the legal basis for the determination of customs value. In both cases, Commission on Tax Disputes has ruled that the transaction value, which was declared by the applicant's (importers), was very small compared with other declared transaction values of another importers, which were accumulated by the customs authorities in the special national PREMI database $^{3}$. Therefore the documents on the customs value of imported goods (leather jackets), submitted by the taxpayer, was not considered sufficient to justify the value of the transaction. Accordingly, the Commission on Tax Disputes, has stated, that the customs authorities has legally made a conclusion that the sale and the price was the subject to some condition or consideration for which a value cannot be determined with respect to the goods. As a 
result, it was recognized that in accordance with Article 29, para. 1, point „b“ of the Community Customs Code 1992, customs valuation of imported goods could not be based on the transaction value method. Therefore, the Commission on Tax Disputes considered that the customs value of imported goods (leather jackets) could be reasonably determined by other methods of customs valuation (based on the provisions of the Article 31 of Community Customs Code 1992), such as the default or fall-back method, that is according to the data, collected in the PREMI database (it includes market prices of imported goods, that is transaction values, declared by other importers to Lithuania). In this context, the question may be raised on reasonableness of Lithuanian tax administrator interpretations about application of customs valuation methods and on the conditions, which allow deviating from the use of transaction value method. In particular, what are the legal reasons, which allow calculating customs value of imported goods based on market prices of other analogous goods, recorded in the special PREMI database, which is formed and maintained by the tax authorities?

It is clear that although after the entry into force of the Free Trade Agreement between the EU and South Korea, the customs duties for the vast majority of goods from South Korea are repealed, but individual commodities (such as agricultural products), will remain the subject to customs duties. In addition, these cases, which were mentioned above, raise important issues on the correct calculation of customs duties for all goods imported to the Republic of Lithuania from the third countries (non-EU members). As it is confirmed by the case law in other cases and can be seen from the perspective of legal doctrine, they reflect the general and universal problems of Lithuanian legal system, such as questioning of a universally and internationally recognized presumption on the transaction value as the basis of customs valuation in the decisions of the national tax authorities. Therefore, this aspect is important and it is necessary to conduct a more detailed analysis of the practice, which was followed by the national institutions, in order to resolve disputes concerning the customs valuation of goods, imported from the South Korea.

It must be stated that the customs value of goods is the most important element of modern customs tariff system. This was repeatedly noted in its practice by the Court of Justice of the European Union (hereinafter - CJEU), which has ruled that the functioning of a customs union requires of necessity the uniform determination of the valuation for customs purposes of goods imported from third countries so that the level of protection effected by the Common Customs Tariff is the same throughout the whole Community (cases Hauptzollamt Bremerhaven v Massey-Ferguson GmbH (1973) and Kommanditgesellschaft in Firma Gebrüder Glunz v Hauptzollamt HamburgWaltershof (1982)). On theoretical level (Radžiukynas et al. 2011, p. 133), it is stressed that the customs value of goods directly influences the efficiency of the tariff regulatory measures of trade, and affects real tax rate, i.e. the 
actual level of customs duties, taxes and other levies. In addition, functioning of the market economy requires application of identical requirements for all economic operators, accordingly, the goods, which are imported or exported by them, shall be the subject to the same rules for calculating of customs duties and other taxes (Bernatonyte 2011).

Therefore, it was an urgent and difficult task is to develop a reasonable system, which could be suitable for all goods (products), for each country, for each type of transactions and could be easily applied. The main customs valuation principles was set at the WTO level only in 1994 by the General Agreement on Tariff and Trade (hereinafter - GATT) and its Article VII (Lietuvos Respublikos Seimas 2001). However, the most important document for customs valuation of goods is the Agreement on the Implementation of Article VII of the GATT 94. According to the Agreement on the Implementation of Article VII of the GATT 94 (Lietuvos Respublikos Seimas 2001), the transaction value should be used to the greatest extent possible in ascertaining the customs value of goods. This primary basis for the valuation of imported goods is defined as the price actually paid or payable for the goods when sold for export to the customs territory, subject to specific qualifications and adjustments (the same provisions are enshrined in the Article 29 of the Community Customs Code 1992). This means that the main standard rule applied for the customs valuation in the EU is that the customs value of imported goods should be considered as the transaction value, provided that the sale or price is not subject to some condition or consideration for which a value cannot be determined with respect to the goods being valued (Terra, Wattel 2012, p. 277; Lyons 2008, p. 290-291).

Where the transaction value cannot be utilized, four alternative methods of establishing the customs value are provided, such as the value of identical goods; the value of similar goods; the value based on unit price: the deductive method and the computed value. These are to be employed strictly following the hierarchical order (Bernatonytė 2011; Menciūnienė, Rugienytė, Simanavičienè 2009; Radžiukynas 2003). Accordingly, only to the extent that the customs value of goods cannot be ascertained by these alternative methods (Lyons 2008, p. 291) the value should be determined on the basis of data available in the Community, using reasonable means consistent with the principles and general provisions of the Agreement on the Implementation of Article VII of GATT 94 and Article itself (Article 31.1 of the Community Customs Code 1992).

Thus, in accordance with international standards, in order to determine the customs value of goods, the transaction value method should be applied primarily. If there are no possibilities to apply this method, possibilities of application of other methods should be considered and finally, if all options used, customs value may be determined using other acceptable methods of customs valuation (fall-back or default method), provided that they are not 
contrary to the Article VII of GATT Agreement. In this way, as interpreted by the CJEU (cases Hans Sommer GmbH\&Co KG v Hauptzollamt Bremen (2000), Unifert Handels GmbH v. Hauptzollamt Münster (1990), Hauptzollamt Itzehoe v H. J. Repenning GmbH (1986), Ospig Textilgesellschaft KG W. Ahlers $v$ Hauptzollamt Bremen-Ost (1984)), it is possible to achieve the objective of the Community rules on customs valuation to introduce a fair, uniform and neutral system excluding the use of arbitrary or fictitious customs values. Thus, the mere non-compliance of the declared transaction value of imported goods with certain comparative values (for example, the values recorded in the national PREMI database) should not be considered as a sufficient reason for non-recognition of the declared value of goods as their customs value, but could be considered as a reason for raising the doubt and continuing to verify the transactions in order to gather additional evidence (Baronaite 2010; Radžiukynas, Belzus 2008; Paulauskas, Medelienė 2008; Radžiukynas 2011). Similar opinion is provided by foreign authors (e.g. Lyons 2008, p. 301), who put the emphasis that where the customs authorities do have reasonable doubts about the declared value, they may only ask for additional information and provide the person with a reasonable opportunity to respond. Thus, such mismatch and non-compliance of values should only form the basis for determining the customs value using one or the other of the abovementioned specific customs valuation methods and this should be proposed to the taxpayer. However, the example of decisions of the Commission on Tax Disputes on the taxation of goods imported from South Korea, illustrates that such a possibility was not even considered. In addition, the possibility to use other alternative customs valuation methods in order to determine the exact customs usually was not considered in other judicial cases and individual authors distinguish this tendency as a clear trend in national case law (Paulauskas, Medelienè 2008).

Consequently it can be assumed that the Lithuanian tax authorities and even national judicial institutions basically incorrectly interprets exceptions for the use of transaction value method and very widely use "last chance" approach (the default or fall-back method), when the customs value of goods is calculated on the basis of comparable prices which were declared by other importers, importing the same class or kind of goods. In addition, it should be noted, that the default method itself should not automatically mean the simple conversion of the customs value of goods to the average market prices (Radžiukynas, Belzus 2008). The methods of valuation employed in using the default method should remain the transaction value and the four alternative methods discussed above, but applied with a reasonable flexibility (Lyons 2008, p. 310-311). A contrary interpretation, as it was already highlighted in the most recent practice of the Lithuanian Supreme Administrative Court (case $U A B$,,Transchema“ $v$ Customs Department under the Ministry of Finance of Lithuanian Republic (2013)), could violate the prohibition on application 
of arbitrary or fictitious and constitute a breach of a common rule that the determination of customs value, as far as possible, should be based on the transaction value method. Therefore, it can be said that administrative practices in Lithuania, concerning the application of the PREMI databases in order to determine the customs value of goods are not acceptable and must be corrected in the future.

\section{Problems of determination of customs origin of imported goods}

Other important international dimension, which is essential for the legal regulation of customs duties, is the legal institute of customs origin of goods. The legal basis of it is a special Annex of the WTO Agreement that is Agreement on Rules of Origin (Lietuvos Respublikos Seimas 2001). It contains general provisions for determining the customs origin of goods that is the state, which is considered the country of origin of goods for customs purposes. The types of customs duties - regular (conventional) or reduced or preferential, - which should be applicable to the imported goods are determined by this legal factor (Terra, Wattel 2012 p. 275; Lux, 2002 , p. 160). Based on the concept of origin, preferential measures provide for the granting of preferential tariff treatments to goods originating from certain countries, groups of countries or territories (a reduced duty or zero rate) (Jisoo 2015).

Peculiarities of regulation of Lithuanian and EU international trade with East Asian countries, leads to the conclusion that the only country with which EU has made preferential (free) trade agreements is South Korea. However, the Lithuanian case law has not dealt with a dispute concerning the application of this specific agreement and the rules of customs origin, which are established in it. Therefore, a key question on the regulation of such issues in Lithuania is how the Lithuanian courts and other competent authorities interpret general legal criteria of customs origin (goods, which are "wholly obtained" in one country, and goods, which underwent substantial transformation in a certain country) in order to define both non-preferential and the preferential status of the goods. According to the Community Customs Code 1992 (Title II), goods wholly obtained in a single country are originating in that country and goods whose production involved more than one country are deemed to originate in the country where they underwent their last, substantial transformation. Goods originating in a country are those wholly obtained or produced in that country. When production in more than one country is involved (and that is normally the case), goods are deemed to originate where they underwent their last substantial economically justified processing or working (see case Hoesch Metals and Alloys GmbH v Hauptzollamt Aachen (2010)). In general, in order to prove certain customs origin in the EU, special origin certificates 
are required and are mainly used for preferential treatment purposes: certificate EUR.1, EUR.2, or Form A, invoice declaration (Terra, Wattel 2012, p. 275). So, in this respect, the question arises how the burden of proof in determining the origin of goods should be distributed between the importer and the customs authorities? Does the determination of the customs origin, which is completed by the national customs authorities, must always be based on the certificates, provided by country from which the goods were imported and in what cases it has a right to question the legitimacy of the evidence submitted by the importers and its validity and to take into account additional evidence in its sole discretion (ex officio)? These types of disputes have been settled in cases on the taxation of goods imported from the Taiwan and South Korea (administrative case of Vilnius regional administrative court UAB ,Putokšnis “ $v$ Customs Department under the Ministry of Finance of Lithuanian Republic (2010); administrative cases of the Lithuanian Supreme Administrative Court $U A B$ "Baltical" v Customs Department under the Ministry of Finance of Lithuanian Republic (2014) and UAB “Žalvaris" v Customs Department under the Ministry of Finance of Lithuanian Republic (2014). There the courts tried to answer the question whether, according to the general rules of origin, these countries could be considered as the countries of customs origin for the imported goods.

In general, addressing of these issues in the practice of the CJEU (see cases Pascoal \& Filhos Ld. v. Fazenda Pública (1997) and CAS SpA v Commission (2008)) is based on the assumption that the basic element of the relationship between importing and exporting states in relation to the verification of origin is the system where the origin is being established by the authorities of the exporting country. This is justified by the fact that the authorities of the exporting country are in the position to verify directly the facts, which determine origin. However, as it was noted by the CJEU, the authorities concerned on both sides must monitor the system jointly and the mechanism of it can function only if the customs authorities of the importing country accept the determinations legally made by the authorities of the exporting country. What regards the importation of goods from East Asia (Taiwan and South Korea), the need to recognize the decisions made by the customs authorities of the exporting countries on approval of the customs origin of goods is also stressed by the Lithuanian courts. In light of these considerations, for example the Vilnius regional administrative court (administrative case $U A B$,Putokšnis “ $v$ Customs Department under the Ministry of Finance of Lithuanian Republic (2010)) has acknowledged that the investigation on the determination of customs origin of the imported goods was carried out by the competent authorities of the exporting country, in accordance with the provisions of their national legislation, so there is no reason to disregard it in determining the customs origin of goods. 
On the other hand, this rule is not absolute, and the practice of the CJEU, as well as the legal doctrine (Lyons 2008, p. 279) confirms that if the customs office has reasonable doubts on the certainty of the certificates of customs origin, it can carry out an additional investigation (post-clearance checks) (case Les Rapides Savoyards v Directeur General des Douanes et Droits Indirects (1983)). When verification shows that a certificate of origin is inaccurate, the importer will be likely, subsequently be faced with a claim for post-clearance recovery of customs duty (see joined cases $C T$ Control (Rotterdam) $B V$ and JCT Benelux BV v Commission (1993) and case Criminal Proceedings Against Edmond Huygen and others (1993)). CJEU has pointed out that in such case, a prudent trader aware of the rules must be able to assess the risks inherent in the market, which he is considering, and accept them as normal trade risks (case Amministrazione delle Finanze v Enterprise Ciro Acampora (1980)). However, the practice of the CJEU falls short of defining exact conditions for such verification procedures and the guarantees applicable to importers, although it is noted, that the risks which the traders must take in such cases are not "unlimited" (Kaufring and Others v Commission (2001)). This gap of legal regulation and practice is essentially filled by the Lithuanian case law in cases, related to the application of anti-dumping duties. There the national case law has established the additional guarantees to the importers and obliged the customs authorities to carry out additional investigations of the documents (evidence) and even the nature of economical operations with goods in order to determine their true customs origin. For example, in cases concerning imports of silicon products, which were processed in Taiwan, the Supreme Administrative Court of Lithuania has repeatedly ruled that Lithuanian customs wrongly considered China as the country of their customs origin and had no legal reason to apply anti-dumping customs duties, which were applicable by the EU for such goods, imported from China (cases UAB "Baltical" v Customs Department under the Ministry of Finance of Lithuanian Republic (2014) and UAB “Žalvaris" v Customs Department under the Ministry of Finance of Lithuanian Republic (2014)). Thus, the Supreme Administrative Court of Lithuania acknowledged that the duty to prove the customs origin of goods, which are subject to anti-dumping customs duties, must be imposed on the national customs authorities. This means that these institutions must prove the legality of the anti-dumping duties and therefore prove the connection between the origin of the imported goods and their processing in another country. Meanwhile, the taxpayer is only sufficient to prove the mere existence of business operations, which are useful to him. Hence, the Court defended the rights and interests of taxpayers (importers of goods) and substantially restricted the conditions for the application of antidumping duty on goods of Taiwan origin as well as noted that the customs authorities cannot hinder international trade formally collecting evidence on the customs origin of goods. 


\section{Problems of tariff classification of goods}

The rapid increase of international trade has led to unification and simplification of international nomenclature, used for the tariff classification of goods for customs purposes. The legal framework for this process was established by the international Harmonized Commodity Description and Coding System Convention (hereinafter - Harmonized System or HS convention), signed in Brussels on 14 June, 1983 (Lietuvos Respublikos Seimas 2003). Each country, which has ratified the HS convention (Lithuania joined it on 1 January, 1995), undertook the responsibility to comply with the basic classification rules for its application as well as obliged to take into account all the notes, regarding the interpretation of its certain sections, headings and subheadings and not to modify the content of its sections, their headings and subheadings (Radžiukynas et al. 2011, p. 115-116).

It should be emphasized that the HS Convention provides only a general rules on the creation of Harmonized System for the tariff classification of goods. Meanwhile, the multipurpose nomenclature of goods, where each position is encoded using the six-digit digital code, is further detailed and explained in the Harmonized System Explanatory Notes (hereinafter - HSENs), which were developed by the World Customs Organization (hereinafter WCO). On the other hand, the attention is often drawn on the compatibility of HSENs with the EU law and, specifically, its accordance with the Combined Nomenclature of the EU, enshrined in Council Regulation No. 2658/87 on the tariff and statistical nomenclature and on the Common Customs Tariff 1987 and its subsequent amendments. While the Combined Nomenclature of the EU was prepared on the basis of the Harmonized System, incorporating its rules into EU law, but in practical terms there are discrepancies between them (Weerth 2008). Accordingly, in practice such situations were examined by the CJEU, which has numerously pointed out that in case when there are no Community rules, which could be applied in order to resolve questions concerning the tariff classification of goods, interpretations provided by the HSENs must be taken into account ${ }^{4}$. In other cases (Douneagent der $N \mathrm{~V}$ Nederlandse Sooprwegen v Inspecteur der Invoerrechten en Accijinzen (1975), Gijs van de Kolk-Douane Expediteur BV v Inspecteur der Invoerrechten en Accijinzen (1990), the Court has said, that the provisions of the HSENs can be set aside only if they appear to be incompatible with the wording of the heading of the Combined Nomenclature or goes manifestly beyond the discretion conferred on the WCO.

This reveals two problems, firstly, what is the legal power of the HSENs in the process of classification of goods for customs purposes and is it possible to apply them directly in the national legal system? In Lithuanian case law such problem may be illustrated by the case in Vilnius regional administrative court where the importer has challenged the taxation of shellfish products, 
imported from South Korea (UAB "Plungès kooperatine prekyba" v Customs Department under the Ministry of Finance of the Lithuanian Republic (2012)). In this case Vilnius regional administrative court based his assessment of the tariff classification of imported goods in both on the provisions of EU Combined Nomenclature, as well as with explanations, provided in HSENs. However, the Court followed short of specifying the exact relationship between these two sources of law. On the other hand, there are examples in Lithuanian case law where the national courts simply made conclusions that it is necessary to follow HSENs in order to ensure correct classification of goods (administrative case of the Supreme Administrative Court of Lithuania $U A B$ "Energetikos tiekimo baze" $v$ Customs Department under the Ministry of Finance of the Lithuanian Republic (2010)). Therefore, if, in accordance with the practice of the CJEU, explanations of HSENs should be considered as a binding source of law in individual cases, it should be noted that the relevant version of HSENs has not yet been translated into Lithuanian language and is not published in official registers of legal acts. Thus, at present there is a problem of access to HSENs, and this problem is further complicated because HSENs uses some specific technical and legal definitions which could hardly be interpreted by non-experts (Laurinavičius et al., p. 203-204). It is obvious that such gap in legal regulation does not ensure functioning of an effective system for tariff classification of goods in Lithuania, as it is confirmed by the practical examples of disputes, which arise from trade with East Asian countries.

Secondly, the practical examples, which were specified above, support the fact that so far administration system for the classification of goods in Lithuania has some problems, which diminish its efficiency and objectivity. At the theoretical level (Laurinavičius et al. 2014) it is noted that advances in technology, appearance of new unknown products, makes it difficult to determine the correct classification code and often requires special expertise, additional laboratory tests, access to manufacturing procedures of goods and their functioning. In the abovementioned case (UAB "Plunges kooperatine prekyba" v Customs Department under the Ministry of Finance of the Lithuanian Republic (2012)), concerning taxation of shellfish products imported from South Korea, the Vilnius regional administrative court has pointed out that in such cases, all customs offices and other persons should have to rely on the conclusions of special customs institution, i.e. the Customs Laboratory. In order to challenge the conclusions of the Customs Laboratory on the classification of goods the taxpayer should submit a similar conclusion of competent EU authority on the determination of tariff classification code. On the other hand, such requirement is not imperatively established in the Community Customs Code 1992 (Article 21). In addition, in some of its other cases Lithuanian Supreme Administrative Court has ruled that the research protocols and conclusions of the Customs Laboratory do not have 
an exclusive legal value as evidence in the judicial proceedings ${ }^{5}$. Recent trends of case law in tax disputes with customs authorities also confirms that all evidence on the relevant classification of goods should be taken into account, not limiting at conclusions, findings and research results provided by tax administrator or its institutions (such as Customs Laboratory) (administrative case of the Supreme Administrative Court of Lithuania UAB "Acme Europe" v. Customs Department under the Ministry of Finance of the Lithuanian Republic (2015)). However, it has to be noted that this principle has not yet been clearly established at the level of legal regulations.

\section{Conclusions}

In recent years (since 2004) Lithuanian trade relations with East Asian countries is characterized by a coherent trade development as these countries are increasingly becoming a significant foreign trade partners to the Republic of Lithuania. Taking into account this group of countries, the most important partners in import operations, which recorded the highest trading volumes, were Taiwan and South Korea, while the main partners for Lithuanian exports were Singapore, Hong Kong and South Korea. In this context, having in mind the objective for the diversification of Lithuanian foreign trade and avoiding dependence on traditional foreign trade partners, such as Russia, an important issue is the creation of attractive legal conditions for the international trade with the countries of East Asia. First of all, ensuring of such conditions is related to application of customs duties (indirect import taxes) which have a unique role and influence on international trade.

The examination of the international trade and customs duties regulation regimes, which the EU applies to the East Asian countries, based on EU Common Commercial Policy, leads to the conclusion that they vary from bilateral (regional) trade regime towards South Korea (based on free trade agreement which lifted most of the trade bariers) to multilateral trade regime towards Singapore, Taiwan and Hong Kong, when international trade relations are governed by the main principles of the WTO agreements. However even the implementation of EU Common Commercial Policy for the regulation of the EU's international trade, albeit limiting the sovereignty of EU member states (such as Lithuania) on these issues, actually does not eliminate it, and provides opportunities for national measures to have a direct effect on the foreign (international) trade.

The analysis of these regulatory measures, related to the application of customs duties on goods imported to Lithuania from East Asian countries, and national practices of their implementation leads to the conclusion that the number of litigation cases between importers and Lithuanian customs 
authorities is constantly growing (especially what regards goods imported from Taiwan, Singapore and South Korea). Mostly, these cases were related to the correct determination of the customs value (the proper application of customs valuation methods which are described in international legislation), distribution of the burden of proof on the customs origin of goods between the taxpayer (importer) and the tax authorities (customs offices) and the functioning of national system used for the tariff classification of goods for customs purposes.

The analysis of judicial cases shows that Lithuanian tax authorities and even national judicial institutions basically incorrectly interprets exceptions for the use of transaction value method for customs valuation and very widely use the "last chance" approach (the default or fall-back method for customs valuation). However, it also can be noticed that in cases for determining the customs origin of goods the Supreme Administrative Court of Lithuania has even expanded application of the precedents and doctrines of the Court of Justice of the European Union. There the national courts has efficiently defended the rights and interests of taxpayers (importers of goods) substantially restricting the rights of customs authorities to challenge the customs origin of goods basing it on formally collected evidence.

Besides, as it can be seen form the practice of cases, related to the classification of goods, there are also some obstacles to its efficient functioning, such as accessibility of certain legal sources (Harmonized System Explanatory Notes) and problems on the recognition of legal value of an additional sources of evidence presented in judicial proceedings.

\section{References}

Baronaite, M., 2010. Naudotų apgadintų transporto priemonių muitinio vertinimo ypatumai. Teise, 77, pp.63-80.

Bernatonytė, D., 2011. Tarptautine prekyba. Kaunas: Technologija.

Bossche, P., 2013. The law and policy of the World Trade Organization: text, cases and materials. Cambridge: Cambridge University Press.

Council Regulation (EEC) No 2658/87 of 23 July 1987 on the tariff and statistical nomenclature and on the Common Customs Tariff 1987. OJ L 256.

Council Regulation (EEC) No 2913/92 of 12 October 1992 establishing the Community Customs Code 1992. OJ L302.

Daukšienè, I., 2011. Pasaulio Prekybos Organizacijos ginčų sprendimo tarybos sprendimai Europos Sajungos teisès sistemoje. Jurisprudencija, 18(3), pp.905-920. 
European Commision, 2015. EU-Singapore Free Trade Agreement. Available at: < http:// trade.ec.europa.eu/doclib/press/index.cfm?id=961> [Accessed 15 September $2015]$.

Folsom, R. F., Gordon, M. W., Spanogle, J. A, 2004. International Trade and Economic Relations: 3 'd edition. St. Paul, USA: Thomson West, a Thomson business.

Herdegen, M., 2013. Principles of International Economic Law. Oxford: Oxford University Press.

Hirst, P., Thompson G., 1992. The Problem of Globalization: International Economic Relations. National Economic Management, and the Formation of Trading Blocs Economy and Society, 21(4), pp.357-396.

INFOLEX PRAKTIKA, (n.d.). Teismu apžvalgos, konsultacijos, nutarimai, sprendimai, nutartys. Available at: <http://www.infolex.lt/praktika/> [Accessed 16 September 2015].

Jisoo, L., 2015. Rules of origin and the use of free trade agreements: a literature review. World Customs Journal, 9(1), pp.43-58.

Jusčius, V., 2006. Ekonomikos internacionalizacijos ir globalizacijos poveikis gamybos paskirstymo - vartojimo santykiu raidai. Habilitacijos procedūrai teikiamy mokslo darbu apžvalga. Kaunas: Kauno technologijos universitetas.

Langvinienè, N., Žitkienè, R., 2011. Opportunities for Lithuania to become a full member of international services market. Societal Studies, 3(3), pp.929-944.

Laurinavičius, A., Sarapinienė, S., Gurevičienė, J. J., Martiuševskaja, E., Jablonskis, A., 2014. Muitinè tarptautinès prekybos logistinèje grandinejje. Vilnius: Mykolo Romerio Universitetas.

Leach, R., 2007. Europa. Glausta Europos Sajungos enciklopedija. Vilnius: Vaga.

Leal-Arcas, R., 2011. International Trade and Investment Law. Multilateral, Regional and Bilateral Governance. Cheltenham, UK: Edward Elgar Publishing Ltd.

Leal-Arcas, R., 2008. Theory and Practice of EC External Trade Law and Policy. London: Cameron May.

Lietuvos Respublikos Seimas, 2001. Istatymas dèl Pasaulio Prekybos Organizacijos steigimo sutarties ir jos priedų ratifikavimo, 24 April, Nr. IX-292. Available at: <www.lrs.1t> [Accessed 12 September 2015].

Lietuvos Respublikos Seimas, 2001. Pasaulio Prekybos Organizacijos steigimo sutartis, 31 May, Nr. 46-1620. Available at: <www.lrs.lt> [Accessed 13 September 2015].

Lietuvos Respublikos Seimas, 2003. Tarptautine suderintos prekiu aprašymo ir kodavimo sistemos konvencija, June 27, Nr. 61-2772. Available at: <www.lrs. 1t> [Accessed 11 September 2015].

Lietuvos Respublikos Seimas, 2004. LR mokesčiu administravimo ịstatymas, 13 April, Nr. IX-2112. Available at: <www.lrs.lt> [Accessed 12 September 2015].

Lietuvos Respublikos statistikos departamentas, 2015. Teminès lentelès, Eksportas, importas pagal valstybes (2004 m. - $2014 \mathrm{~m}$. sausio - gruodžio mèn.). Available at: <http://osp.stat.gov.lt/temines-lenteles43 > [Accessed 10 September 2015]. 
Lietuvos Respublikos ūkio ministerija, 2015. Lietuvos eksporto plètros 2014-2020 metu gairès, 27 January, Nr. 4-58. Available at: < https://www.e-tar.lt/portal/ index.html $>$ [Accessed 15 September 2015].

Linarelli, J., 2014. How Trade Law Changed: Why it Should Change Again. Mercer Law Review, 65(3), pp.621-667.

Lux, M., 2002. Guide to Community Customs Legislation. Bruxelles: Bruylant. Lyons, T., 2008. EC Customs law. Oxford: Oxford University Press.

Menciūnienė, V., Rugenytė, D., Simanavičienė, Ž. 2009. Importuojamų prekių muitinès vertės nustatymo metodų taikymas besivystančiose šalyse. Verslas, vadyba ir studijos, 8(1), pp.79-95.

Paulauskas, A., Medelienė, A., 2008. Sandorio vertė kaip prekių muitinio ịvertinimo pagrindas. Teise, 67, pp.25-47.

Povilauskienè, D., 2006. Teisé ir muitinès veikla. Vilnius: Mykolo Romerio universitetas.

Radžiukynas, J., 2003. Kai kurios importuojamų prekių muitinès vertès nustatymo problemos. Jurisprudencija, 46(38), pp.97-106.

Radžiukynas, J., 2005. Importuojamų prekių muitinio įvertinimo kontrolè Lietuvos muitinejje Europos Bendrijos muitinių strategijos kontekste. Jurisprudencija, 73(65), pp.48-57.

Radžiukynas, J., 2005. Importuojamų prekių muitinio įvertinimo kontrolè Lietuvos muitineje Europos Bendrijos muitinių strategijos kontekste. Jurisprudencija, 73(65), pp.48-57.

Radžiukynas, J., Belzus, A., 2008. Importuojamu prekiu muitinis ìvertinimas ir kontrolè. Vilnius: Lietuvos prekybos, pramonès ir amatų rūmų asociacija.

Radžiukynas, J., Rimkus, V., Sarapinienė, S., Žitkienė, R., Povilauskienė, D., 2011. Europos Sajungos bendroji prekybos politika. Vilnius: Mykolo Romerio Universitetas.

Raišutis, A., 2005. Lietuvos Respublikos muitų teisès savarankiškumo problematika. Jurisprudencija, 70(62), pp.74-80.

Rimkus, V., 2005. Vidaus rinkos apsaugos priemonių taikymas Lietuvoje. Jurisprudencija, 73(65), pp.96-105.

Slavickienè, A., Jatkūnaitė, D., 2006. Muitų politikos perspektyvos Lietuvai tapus ES nare. In: Tarptautinès mokslinès konferencijos ,,Vadybos mokslas ir studijos kaimo verslų ir ju infrastruktūros plètrai" medžiaga. Kaunas, Republic of Lithuania, 2006. Kaunas: Akademija.

Terra, B. J. M., Wattel, P. J., 2012. European Tax Law - 6th edition. Alphen aan den Rijn: Wolters Kluwer Law \& Business.

The European Union-South Korea Free Trade Agreement 2011. OJ L 127.

The Directorate General for Trade of the European Commission, 2015. Countries and regions. Available at: <http://ec.europa.eu/trade/policy/countries-and-regions/> [Accessed 10 September 2015]. 
Thuronyi, V., 2003. Comparative Tax Law. The Hague: Kluwer Law International.

Weerth, C., 2008. HS 2007: Notes of the Tariff Nomenclature and the Additional Notes of the EC. World Customs Journal, 2(1), pp.111-116.

Woolcook, S., 2008. The potential impact of the Lisbon Treaty on European Union External Trade Policy. Stockholm: Swedish Institute for European Policy Studies.

Administrative case of the Lithuanian Supreme Administrative Court UAB "Baltical" v Customs Department under the Ministry of Finance of Lithuanian Republic [2014] A-261-146/2014.

Administrative case of the Lithuanian Supreme Administrative Court UAB "Žalvaris" v Customs Department under the Ministry of Finance of Lithuanian Republic [2014] A-261-144/2014.

Administrative case of the Lithuanian Supreme Administrative Court UAB "Energetikos tiekimo baze" $v$ Customs Department under the Ministry of Finance of Lithuanian Republic [2010] A-261-1408/2010.

Administrative case of the Lithuanian Supreme Administrative Court "Acme Europe" v. Customs Department under the Ministry of Finance of the Lithuanian Republic" [2015] A-276-442/2015.

Administrative case of the Supreme Administrative Court of Lithuania $U A B$ „, Transchema" $v$ Customs Department under the Ministry of Finance of Lithuanian Republic [2013] Administrative Jurisprudence 25, A-442-709/2013

Administrative case of Vilnius regional administrative court UAB ,Putokšnis “ $v$ Customs Department under the Ministry of Finance of Lithuanian Republic [2010] Ik-1487-473/2010.

Administrative case of Vilnius regional administrative court UAB "Plungés kooperatine prekyba" $v$ Customs Department under the Ministry of Finance of the Lithuanian Republic [2012] I-3286-580/2012.

Case of the Commission on Tax Disputes of the Republic A. G. v Customs Department under the Ministry of Finance of Lithuanian Republic [2006] S-319(7-301-2006).

Case of the Commission on Tax Disputes of the Republic E. D. v Customs Department under the Ministry of Finance of Lithuanian Republic [2006] S-308-(7-2852006).

Amministrazione delle Finanze v Enterprise Ciro Acampora [1980] ECR 3731, C-827/79.

CAS SpA v Commission [2008] ECR I-6135, C-204/07.

Criminal Proceedings Against Edmond Huygen and others [1993] ECR I-6381, C-12/92.

CT Control (Rotterdam) BV and JCT Benelux BV v Commission [1993] ECR I-3873, C-121/91 and C-122/91.

Douneagent der NV Nederlandse Sooprwegen v Inspecteur der Invoerrechten en Accijinzen [1975] ECR 1439, C-38/75. 
Gijs van de Kolk - Douane Expéditeur BV v Inspecteur der Invoerrechten en. Accijnzen [1990] ECR I-265, C-233/88.

Hans Sommer GmbH\&Co KG v Hauptzollamt Bremen [2000] ECR 35, C-15/99.

Hauptzollamt Bremerhaven v Massey-Ferguson GmbH [1973] ECR 897, C-8/73.

Hauptzollamt Itzehoe v H. J. Repenning GmbH [1986] ECR 1873, C-183/85.

Hoesch Metals and Alloys GmbH v Hauptzollamt Aachen [2010] ECR I-951, C-373/08.

Kaufring and Others v Commission [2001] ECR II-1337, joined cases T-186/97, T-187/97, T-190/97

Kommanditgesellschaft in Firma Gebrüder Glunz v Hauptzollamt Hamburg-Waltershof [1982] ECR 197, C-248/80.

Les Rapides Savoyards v Directeur General des Douanes et Droits Indirects [1983] ECR 3105, C-218/83.

Ospig Textilgesellschaft KG W. Ahlers v Hauptzollamt Bremen-Ost [1984] ECR $\mathrm{I}-00609, \mathrm{C}-7 / 83$.

Pascoal \& Filhos Ld. v. Fazenda Pública [1997] ECR I-4209, C-97/95.

Unifert Handels GmbH v. Hauptzollamt Münster [1990] ECR I-2275, C-11/89.

\section{Notes}

1 See for example official information of the Directorate General for Trade of the European Commission, available at $<\mathrm{http} / /$ ec.europa.eu/trade/policy/countries-andregions/countries/russia/ $>$ [Accessed 10 September 2015].

2 Globally, the goods are classified for customs purposes under the provisions of Harmonized System, set by the Brussels convention on the tariff classification of goods (1983); the EU applies its own Combined Nomenclature, which is based on the Harmonized System

3 The reliability of the transaction value of imported goods is usually verified by Lithuanian customs authorities with PREMI (customs valuation of goods) database, which includes data on imports of goods over the last three months, such as importers, the value of the declared transactions and the amount of the imported goods.

4 See, for example, cases of the Court of Justice of the European Union No. C-14/70; C-12/71; C-35/75; C-459/93; C-280/97; C-42/99, C-396/02, C-206/03, C-208 and 209/06, C-4586/06.

5 See, for example, cases of the Supreme Administrative Court of Lithuania No. A-14371/2013, A-442-1723/2012, A-575-1238/2012, A-556-1010/2009, A-143-561/2010, A-556-1010/2009, A-143-1314/2008, A-261-214/2008, A-10-952/2006, A-8-922/2006. 


\section{About Author}

\section{Gediminas VALANTIEJUS}

He has graduated from the Vilnius University Faculty of Law (2002), where he gained his Master of Laws degree. Since 2012 he works as a lecturer at the Mykolas Romeris University, Faculty of Economics and Finance Management, Institute of Finance where he is teaching subjects on the European Union (EU) finance, tax and customs law for the students, studying in law and economics study programs. He is currently completing Ph.D. studies in the law degree program at the Law Faculty of Mykolas Romeris University (Lithuania), Institute of International and European Union Law (started in October, 2014, expected in 2018) and is preparing a doctoral dissertation on the theme "Problems of legal regulation of customs duties in the international trade between the European Union, Russia, India and China ". The areas of his research include regulation of international trade, problems of international economic and trade law as well as EU customs law/EU Common Commercial Policy. $\mathrm{He}$ is also the author of several publications and presentations on the related topics, focussing on the legal aspects of international trade relationships between the EU Member States and third countries (such as "Problems of Customs Legal Regulation in International Trade between the European Union, Russia and China: Analysis of Lithuania Judicial Practice since 2010", Mykolas Romeris University, 2015; "Problematic Aspects of International Trade between the United States of America and the Republic of Lithuania in the Lithuanian Judicial Practice", Mykolas Romeris University, 2015; "Application of Soft Law Instruments in International Economic Law: Insights on Lithuanian Practice on the Legal Regulation of Customs Duties", Mykolas Romeris University, 2016 and etc.). 